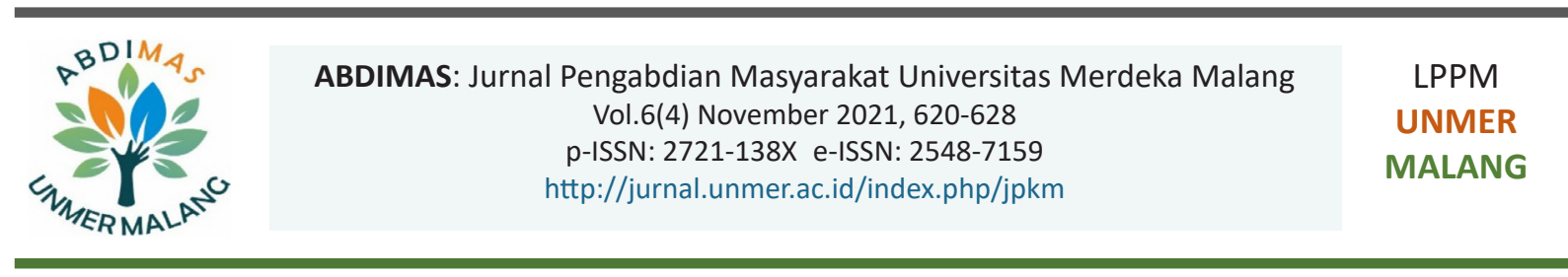

\title{
The education, training, and coaching of household businesses producers of Opak Gambir
}

\section{Pendidikan, pelatihan, dan pembinaan usaha rumah tangga penghasil Opak Gambir}

\author{
Lilik Kustiani, Kurnia Isnuwardiati, Diah Widiawati, Dyah Setyawati \\ Departemen Manajemen, Fakultas Ekonomi dan Bisnis, Universitas Merdeka Malang \\ Jl. Terusan Raya Dieng No.62-64 Malang, 65146, Indonesia
}

\begin{abstract}
ARTICLE INFO
Received: 2021-04-26

Revised: 2021-06-10

Accepted: 2021-08-17

Keywords:

Education and training, Entrepreneurship, Opak Gambir household business

\section{ABSTRACT}

Selorejo Village, Blitar Regency is a village where some of the residents produce Opak Gambir snacks which are still managed using traditional methods. This causes the management in the production to be less professional and less organized. This program aims to improve education and training, especially in the fields of entrepreneurship, finance and marketing, so that the management of this home industry will be more organized and professional. The method of implementing the program is by providing education, training and coaching for producers of Opak Gambir. The results of the program show that the craftsmen are very well educated about the principles of entrepreneurship. Producers of Opak Gambir also able to make financial plans both for administration and also the selling price of their products. The craftsmen are also able to determine marketing plans, which include starting from the process of determining prices, determining distribution locations and how the promotion process is carried out. Through this service, it is hoped that the producer will be able to manage their business in a professional manner, apart from being a source of income, is also a destination for the Opak Gambir industry.
\end{abstract}

(C)2021 Published by University of Merdeka Malang. This is an open access article distributed under the CC BY-SA 4.0 license

(https://creativecommons.org/licenses/by-sa/4.0/)

How to cite: Kustiani, L., Isnuwardiati, K., Widiawati, D., \& Setyawati, D. (2021). The education, training, and coaching of household businesses producers of Opak Gambir. Abdimas: Jurnal Pengabdian Masyarakat Universitas Merdeka Malang, 6(4), 620-628. https://doi.org/10.26905/abdimas.v6i4.5741

\section{PENDAHULUAN}

Sumber daya manusia yang berkualitas selalu dituntut untuk mengikuti perkembangan ilmu pengetahuan dan teknologi (Nasrika, 2019), serta memiliki wawasan global agar bisa berkompetisi dan memenangkan kesempatan merebut pasar serta menyalurkan hasil usahanya agar bisa mewujudkan apa yang menjadi tujuan dalam mengelola usahanya yaitu terwujudnya pencapaian profit yang cukup tinggi.

Di Desa Selorejo Kecamatan Selorejo Kabupaten Blitar, ada banyak masyarakat yang menjalankan kegiatan sehari-harinya dengan memproduksi makanan (camilan) yang biasa disebut Opak Gambir. Opak 
Gambir atau yang lebih dikenal masyarakat "kue semprong" merupakan makanan atau jajanan yang banyak digemari masyarakat karena mempunyai cita rasa manis dan gurih (Septiani, 2013). Memproduksi Opak Gambir ini merupakan usaha yang dilakukan untuk menambah pendapatan keluarga sebagai pemenuhan kebutuhan hidupnya.
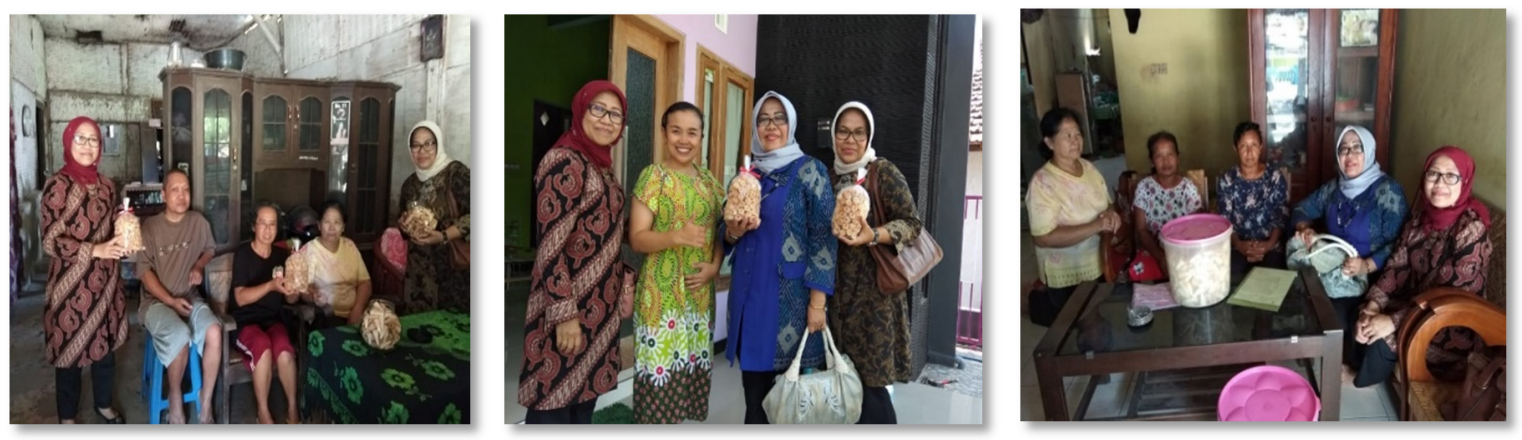

Gambar 1. Para produsen Opak Gambir dengan hasil produksinya

Usaha rumah tangga ini nantinya selain sebagai sumber pendapatan bagi keluarga yang cukup besar diharapkan juga bisa membantu program pemerintah dalam rangka mengentaskan kemiskinan dengan jalan memberi peluang bagi masyarakat yang berkemampuan untuk membuat Opak Gambir dan sekaligus bisa menyerap tenaga kerja yang bisa disalurkan untuk menjadi tenaga yang bisa membukukan ataupun bisa memasarkan produksinya. Industri rumah tangga membantu meningkatkan penghasilan keluarga (Syahdan, 2019). Pemberdayaan industri rumah tangga dapat mendukung usaha pemerintah untuk meningkatkan kesejahteraan ekonomi masyarakat (Riyansyah et al., 2018). Di Desa Selorejo Kecamatan Selorejo Kabupaten Blitar, masyarakat penghasil Opak Gambir rata-rata mempunyai tenaga kerja tiga sampai lima orang baik dari keluarganya sendiri maupun diambil tenaga kerja dari masyarakat sekitarnya, rata rata tenaga kerja tersebut mampu membuat Opak Gambir dengan kualitas, rasa, dan bentuk cukup enak dan baik. Permasalahan yang dihadapi oleh pelaku usaha Opak Gambir yaitu penjualan yang relatif rendah, banyak produk yang rusak dikarenakan proses produksi yang kurang baik, sulit menentukan persediaan bahan baku yang dibutuhkan, serta kurang dalam pengelolaan keuangan terutama dalam menentukan biaya produksi dan tingkat keuntungan. Dilihat dari segi pengemasan juga masih sederhana, Opak Gambir hanya menggunakan plastik sehingga rentan produk mengalami kerusakan jika tidak dilakukan dengan hati-hati yang berakibat pada kerugian. Promosi yang dilakukan pelaku usaha hanya dari mulut ke mulut, sehingga produk kurang dikenal masyarakat luas. Kinerja usaha kecil menengah dapat ditingkatkan dan dikembangkan dengan melakukan beberapa hal, antara lain mengembangkan tujuan pemasaran, mengembangkan daerah pemasaran, mengembangkan pengelolaan keuangan, dan memperhatikan keinginan konsumen (Andarini, 2012).

Tujuan pengabdian masyarakat ini adalah untuk mengatasi kesulitan pelaku usaha Opak Gambir dalam hal keuangan dan pemasaran melalui pendidikan, pelatihan dan pembinaan guna meningkatkan pendapatan usaha. Pengelolaan usaha rumah tangga selama ini masih menggunakan metode tradisional. Pelaku usaha hanya menggunakan perkiraan disetiap produksi yang dilakukan. Belum ada pemahaman 
ABDIMAS: Jurnal Pengabdian Masyarakat Universitas Merdeka Malang Volume 6, No. 4, November 2021: 620-628

yang cukup mengenai bagaimana mengelola pemasaran serta mengelola keuangan. Atas situasi dan kondisi inilah, maka pengabdi melakukan program untuk memberikan pendidikan dan pelatihan dalam rangka pembenahan atau penataan tentang pengelolaan keuangan dan pemasaran utamanya ditujukan pada masyarakat yang memiliki usaha rumah tangga penghasil Opak Gambir.

\section{METODE}

Mitra dari program pengabdian masyarakat ini adalah para pengrajin Opak Gambir yang berjumlah 12 orang. Para pengrajin tersebut sehari-hari membuat Opak Gambir di Jalan Raya Selorejo Kecamatan Selorejo Kabupaten Blitar.

Tahap pertama pelaksanaan program diawali dengan diskusi dan identifikasi masalah yang saat ini terjadi pada pengrajin Opak Gambir. Selain untuk saling mengenal setiap anggota, diskusi ini dimaksudkan untuk menemukan permasalahan yang sedang terjadi pada kelompok pengrajin Opak Gambir. Masalah yang saat ini terjadi adalah masih kurang profesional dan kurang efektifnya pengelolaan usaha tersebut.

Tahap kedua, yaitu pengumpulan data. Data diperoleh dengan metode wawancara langsung dengan responden, data yang diperoleh tim pengabdian, menunjukkan bawa semua anggota kelompok pengrajin yang berjumlah 12 orang masih belum memahami betul dengan konsep berwirausaha, bagaimana konsep pemasaran yang tepat, dan bagaimana administrasi pengelolaan keuangan yang baik untuk memudahkan proses administrasi keuangan mereka.

Tahap ketiga, masuk pada penyampaian edukasi mengenai kewirausahaan. Tim pengabdi menyiapkan materi mengenai arti mendasar mengenai wirausaha, lalu ada berapa tipe-tipe wirausaha, sifat-sifat yang perlu dimiliki oleh wirausahawan, karakteristik wirausahawan yang berhasil, dan kegagalan utama seorang wirausahawan. Dengan tetap mematuhi protokol kesehatan yang aman, maka penyampaian edukasi dilakukan dari rumah ke rumah dengan peserta yang terbatas dan hanya anggota keluarga pengrajin saja.

Pelaksanaan kegiatan pengabdian masyarakat ini diawali dengan mengidentifikasi penentuan kebutuhan pelaku usaha Opak Gambir. Kebutuhan yang diperlukan adalah dalam hal keuangan dan pemasaran. Pelaksanaan program dibagi dalam 3 bagian, yaitu metode pendidikan, pelatihan, dan pembinaan. Metode pendidikan meliputi edukasi mengenai pentingnya pemahaman kewirausahaan, tipe wirausaha, sifat wirausaha, karakteristik wirausahawan, dan penyebeb kegagalan wirausaha. Kewirausahaan merupakan karakteristik individu yang mayoritas bertujuan untuk mengelola bisnis agar memperoleh keuntungan. Karakteristik pengelola bisnis (entrepreneuer) memiliki jiwa bisnis, sifat inovatif yang dinamis, dan adaptif dalam menyikapi perubahan pada ilmu pengetahuan dan teknologi (Hadiyati, 2011). Memberikan pendidikan mengenai kewirausahaan akan semakin mendukung masyarakat untuk berwirausaha (Cahyani et al., 2020).

Metode pelatihan di sini para pengrajin Opak Gambir dilatih untuk memahami apa itu pemasaran dan inti pemasaran yang terdiri dari 4P (Product, Price, Place dan Promotion). Metode pelatihan sangat dibutuhkan oleh pelaku usaha kecil menengah salah satunya untuk memberikan pembekalan mengenai pemasaran produk (Kusumawardhani et al., 2020). Keberhasilan pendampingan pelatihan bagi 
masyarakat akan mendorong penyerapan tenaga kerja, meningkatnya pendapatan, serta berpotensi untuk melahirkan para pelaku usaha di masyarakat terutama pada masa-masa produktif (Jatmiko et al., 2015).

Sedangkan untuk metode pembinaan, dilakukan setelah pelaksanaan pendidikan tentang manajemen usaha dan pelatihan selama 6 bulan yang akan dimulai dengan pra-pengabdian yaitu dengan mendata dan mengenal pengrajin Opak Gambir. Pembinaan terhadap usaha rumah tangga merupakan salah satu upaya pemerintah untuk memperluas kesempatan berwirausaha, sehingga para pelaku industri mampu untuk bersaing dalam menjual produk baik produk jasa maupun produk barang (Florita et al., 2018). Pelatihan dan pendampingan serta pembinaan untuk kegiatan produksi semakin mendukung peningkatan penjualan dan pengelolaan keuangan yang semakin efektif (Asmoro et al., 2019). Pelatihan dan pendampingan usaha rumah tangga mendukung masyarakat meningkatkan penghasilan (Anam et al., 2021).

Untuk dapat melaksanakan hal tersebut maka diawali dengan diskusi dan pendekatan kepada pengrajin produk Opak Gambir bahwa nantinya akan diberikan pendidikan, pelatihan, dan pembinaan dalam upaya mencapai peningkatan penghasilan keluarga pengrajin tersebut. Sehingga diharapkan melalui kegiatan tersebut, kualitas sumber daya manusia pengusaha rumah tangga penghasil Opak Gambir di Desa selorejo Kecamatan Selorejo Kabupaten Blitar dapat meningkat.

Tabel 1. Jadwal/schedule dan tahapan pelaksanaan program

\begin{tabular}{|c|c|c|c|}
\hline Waktu & Tahap & Tujuan & Pelaksana \\
\hline 2 hari & Tahap 1 & Pra-survei dengan tujuan untuk mengidentifikasi kebutuhan & Ketua, anggota \\
\hline 1 minggu & Tahap 2 & Survei guna mengumpullkan data & Ketua, anggota \\
\hline 1 hari & Tahap 3 & $\begin{array}{l}\text { Pendidikan dengan tujuan menyampaikan pentingnya } \\
\text { kewirausahaan }\end{array}$ & $\begin{array}{l}\text { Ketua, anggota, dan } \\
\text { pelaku usaha }\end{array}$ \\
\hline 2 hari & Tahap 4 & $\begin{array}{l}\text { Pelatihan pemasaran dan keuangan dengan tujuan untuk } \\
\text { meningkatkan pemahaman pentingnya pemasaran dan } \\
\text { mengelola keuangan }\end{array}$ & $\begin{array}{l}\text { Ketua, anggota, dan } \\
\text { pelaku usaha }\end{array}$ \\
\hline 6 bulan & Tahap 5 & $\begin{array}{l}\text { Pembinaan dengan tujuan peningkatan kemampuan kognitif } \\
\text { dan afektif para peserta }\end{array}$ & $\begin{array}{l}\text { Ketua, anggota, dan } \\
\text { pelaku usaha }\end{array}$ \\
\hline
\end{tabular}

\begin{tabular}{|c|c|c|c|c|}
\hline $\begin{array}{c}\text { Diskusi } \\
\text { (Identifikasi) }\end{array}$ & $\begin{array}{c}\text { Pengumpulan } \\
\text { Data }\end{array}$ & $\begin{array}{l}\text { Penyampaian } \\
\text { Edukasi KWU }\end{array}$ & $\begin{array}{l}\text { Pelatihan } \\
\text { MKT \& KEU }\end{array}$ & Pembinaan \\
\hline
\end{tabular}

Gambar 2. Skema kegiatan

\section{HASIL DAN PEMBAHASAN}

Tim Pengabdian Masyarakat diterima kehadirannya di usaha rumah tangga penghasil Opak Gambir di Desa Selorejo. Selanjutnya Tim Pengabdian Masyarakat memberikan edukasi tentang kewirausahaan dan melakukan tanya jawab pada peserta. Adapun materi edukasi kewirausahaan yang 
ABDIMAS: Jurnal Pengabdian Masyarakat Universitas Merdeka Malang Volume 6, No. 4, November 2021: 620-628

disampaikan seperti tipe-tipe wirausaha dan penyebab kegagalan wirausahawan. Tipe-tipe wirausaha yang dimaksudkan disini meliputi: (1) Wirausaha yang memiliki inisiatif; (2) Wirausaha yang mengorganisir mekanisme sosial dan ekonomi untuk menghasilkan organisasi yang sehat; (3) Wirausaha yang menerima resiko dan kegagalan; (4) Wirausaha ahli; (5) The promoter; dan (6) General manager. Sifatsifat yang perlu dimiliki seorang wirausahawan meliputi: (1) Percaya diri; (2) Berorientasi pada tugas dan hasil; (3) Pengambilan resiko; (4) Kepemimpinan; (5) Keorisinilan; dan (6) Berorientasi pada masa depan. Karakteristik wirausahawan sukses yang diajarkan kepada pengrajin meliputi: (1) Mempunyai visi untuk masa depan; (2) Mengambil keputusan dengan cepat; (3) Menindaklanjuti keputusan yang telah diambil; (4) Melaksanakan kegiatan dengan penuh perhatian; (5) Berdedikasi tinggi terhadap usahanya; (6) Sangat mencintai produk yang dihasilkan; (7) Mampu memperhatikan faktor-faktor kritis secara rinci; (8) Asumsi kesuksesan bukan hanya uang, tapi juga kesuksesan bisnisnya; dan (9) Mampu mendistribusikan kepemilikan usaha terhadap orang-orang yang dipercayainya.

Tim pengabdi juga mengedukasi para pengrajin mengenai penyebab kegagalan wirausahawan, penyebab itu meliputi: (1) Tidak mampu membuat pilihan yang bikan tentang asosiasi usahanya; (2) Tidak memiliki catatan usaha yang baik; (3) Kurang mampu mengelola keuangan dan menggunakan keuangan secara berlebih untuk kepentingan pribadi; (4) Tidak memisahkan uang milik pribadi dan kekayaan perusahaan; (5) Terlibat dalam begitu banyak urusan tanpa memiliki pengetahuan yang memadahi tentang keuangan, pemasaran, dan manajemen umum; (6) Lupa untuk mngendalikan kegiatan usaha secara efektif; dan (7) Mempekerjakan orang tanpa melihat kualifikasi apakah orang tersebut mampu menjalankan kewajiban atau tidak.
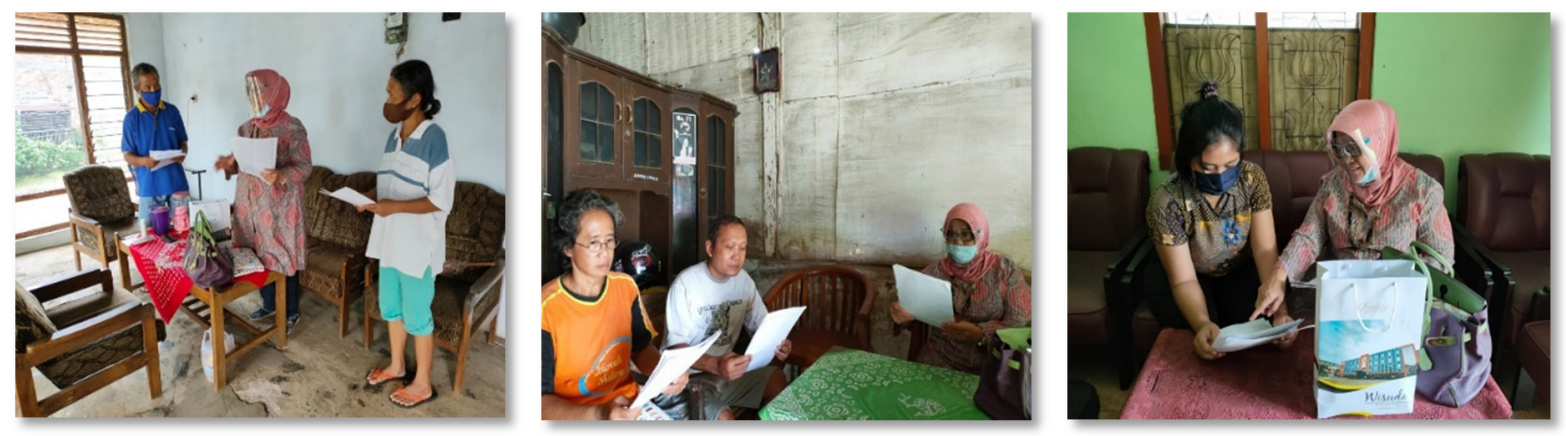

Gambar 3. Penyampaian edukasi mengenai kewirausahaan

Tahap keempat dari pelaksanaan pengabdian ini adalah pelatihan mengenai pemasaran dan keuangan. Pada pelatihan mengenai pemasaran, para pengrajin diberikan pembekalan bagaimana mengenal produk mereka sampai proses promosi. Pada pelatihan pemasaran, akan diedukasi mengenai 4P yang cukup dikenal, yaitu Produk, Price, Place dan Promotion.

Pada pemahaman produk Opak Gambir, para pengrajin diedukasi mengenai nilai manfaat yang terkandung dalam produk sehingga mendorong terjadinya pembelian. Misalnya produk Opak Gambir dengan kualitas rasa yang enak, tahan lama, dan mudah dibawa kemana-mana. Pemberian merek, merek harus mudah diingat, mudah diucapkan, ringkas, dan yang paling penting untuk menambah keyakinan 
konsumen untuk membeli adalah adanya sertifikat halal. Pelabelan, ini juga menjadi salah satu hal yang cukup diperhatikan oleh konsumen jaman sekarang, mereka sangat jeli melihat tanggal produksi dan tanggal kadaluwarsa, ini juga menjadi salah satu pertimbangan dari konsumen untuk membeli. Hal yang tidak kalah penting adalah kemasan, dengan tekstur Opak Gambir yang tipis, diharapkan para pengrajin juga mempertimbangan jenis pengemasan apa yang benar-benar bagus, sehingga konsumen tidak perlu khawatir produk akan remuk apabila membawa camilan tersebut.

Pada pemahaman harga, pengrajin diedukasi bahwa penetapan harga harus diseimbangankan dengan nilai manfaat sehingga akan mengundang minat pembeli. Perlu juga digunakan strategi harga yaitu bahwa harga jual diperoleh dari keseluruhan total biaya ditambah laba yang diinginkan. Penetapan harga juga harus disesuaikan dengan daya beli pasar sasaran. Pada pemahaman lokasi distribusi, pengarajin diedukasi dengan pemahaman bahwa produk Opak Gambir harus mudah dijangkau oleh konsumen, cakupan distribusi tidak hanya pada pasar secara fisik, namun sejalan dengan kemajuan teknologi mungkin bisa dilakukan juga distribusi secara online.

Sedangkan untuk pemahaman promosi, promosi haruslah bersifat memberi tahu, mengingatkan, membujuk, dan bisa mempengaruhi minat beli. Promosi bisa melalui media elektronik, internet, marketplace, media sosial maupun secara fisik seperti penyampaian dari mulut ke mulut (word of mouth).
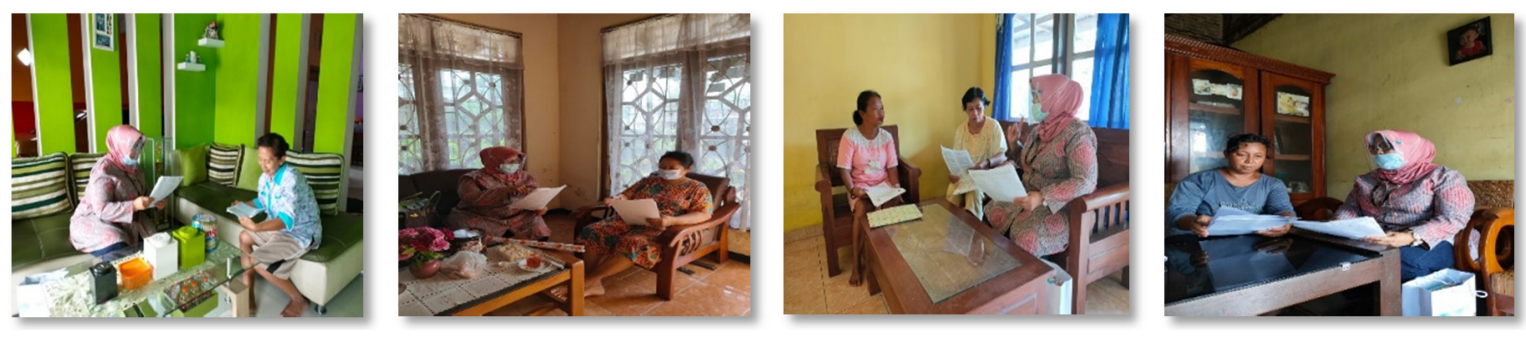

Gambar 4. Pelatihan keuangan bagi pemilik usaha

Pada pelatihan keuangan, secara singkat para pengrajin (khususnya pemilik usaha) dibekali pengetahuan mengenai anggaran produksi, anggaran bahan baku, anggaran upah tenaga kerja, anggaran harga pokok produksi, dan harga pokok produksi.

Pada pemahaman mengenai anggaran produksi, para pengrajin diajarkan untuk menghitung berapa jumlah kebutuhan dana yang akan digunakan dalam satu kali produksi. Perhitungan ini didasarkan pada berapa rencana penjualannya, kemudian dikurangi persediaan akhir (stock) kemudian dari situ dapat diketahui berapa jumlah kebutuhan Opak Gambir yang harus dibuat.

Pada anggaran bahan baku, ini sangat mudah sekali, karena bahan baku yang dibutuhkan hanya tepung beras, gula, telur, santan, garam, dan minyak sedikit untuk olesan maka berdasar pada berapa jumlah yang akan diproduksi dilakukan konversi kebutuhan bahan bakunya. Perhitungannya adalah jumlah dari harga per unit bahan baku dikali dengan harga bahan baku tersebut.

Kemudian untuk anggaran upah tenaga kerja. Upah tenaga kerja adalah rencana kerja yang disusun terperinci tentang upah yang akan dibayarkan kepada tenaga kerja dalam kurun waktu tertentu, 
ABDIMAS: Jurnal Pengabdian Masyarakat Universitas Merdeka Malang Volume 6, No. 4, November 2021: 620-628

karena seluruh pengrajin ini selain sebagai pemilik juga sebagai tenaga kerja, makan perhitungan biaya upah masih tidak terlalu pakem berdasar pada peraturan pengupahan tenaga kerja, akan tetapi upah tersebut juga dimasukkan dalam perhitungan harga pokok produksi.

Serangkaian pelatihan bagian keuangan akan ditutup dengan penentuan harga pokok penjualan. Harga pokok produksi berarti jumlah biaya yang melekat pada produksi yang dihasilkan. Meliputi biayabiaya yang dikeluarkan ketika produksi dimulai, saat pengadaan bahan, proses pembuatan, hingga barang siap jual.

Tabel 2. Cara menghitung harga pokok produksi

\begin{tabular}{ccl}
\hline Tahap & \multicolumn{1}{c}{ Jenis Penghitungan } & \multicolumn{1}{c}{ Cara Menghitung } \\
\hline Tahap 1 & Bahan baku yang digunakan & $\begin{array}{l}\text { Saldo awal bahan baku + Pembelian bahan baku - Saldo } \\
\text { akhir bahan baku }\end{array}$ \\
Tahap 2 & Biaya produksi & $\begin{array}{l}\text { Bahan baku yang digunakan + Biaya tenaga kerja langsung } \\
+ \text { Biaya overhead produksi }\end{array}$ \\
Tahap 3 & Harga pokok produksi & $\begin{array}{l}\text { Total biaya produksi + Saldo awal persediaan barang dalam } \\
\text { proses produksi }- \text { Saldo akhir persediaan barang dalam } \\
\text { proses produksi }\end{array}$ \\
Tahap 4 & Harga pokok penjualan & $\begin{array}{l}\text { Hargan pok produksi + Persediaan barang awal - Persedi- } \\
\text { aan barang akhir }\end{array}$ \\
\hline
\end{tabular}

Tahap kelima atau tahap terakhir yaitu pembinaan. Pada tahap ini pembinaan akan dilakukan selama 6 bulan sejak pra-pengabdian hingga selesai. Untuk menunjang keberhasilan program pengabdian kepada masyarakat yaitu berupa adanya peningkatan kemampuan kognitif dan afektif para peserta dalam memahaminya, maka penyampaian materi pelatihan diberikan dengan cara bertahap. Penyuluhan ini dianggap efektif apabila dapat memberikan perubahan bagi khalayak sasaran dalam menerapkan teori yang diperoleh dalam pendidikan dan pelatihan melalui aktivitas yang sesungguhnya.

Pelatihan telah dilaksanakan menggunakan metode experiental learning, yang berarti bahwa para pengrajin terlibat secara langsung di setiap sesi latihan. Hal tersebut dilakukan dengan cara mendatangi masing-masing rumah pengrajin dan dilakukan ceramah langsung, tanya jawab antara tim pengabdian, dan responden serta belajar bersama untuk melakukan analisis kebutuhan untuk bidang pemasaran dan keuangan. Keberhasilan program pengabdian ini dipengaruhi oleh beberapa hal, antara lain kompetensi tim pengabdian yang memang ahli di bidangnya sehingga materi yang disampaikan benar-benar sesuai dengan kompetensinya serta antusiasme para pengrajin untuk memperoleh ilmu baru. Para pengrajin juga sangat aktif dalam pelatihan, hal ini dibuktikan dengan adanya sejumlah pertanyaan-pertanyaan mengenai sesuatu hal yang belum mereka ketahui dan belum pelaku usaha lakukan selama ini. Melalui pendidikan, pelatihan, dan pembinaan dapat membuka wawasan baru bagi pelaku usaha Opak Gambir di Desa Selorejo Blitar untuk lebih kreatif dalam mengolah Opak Gambir dengan varian rasa dan memikirkan pengemasan yang lebih menarik sebagai oleh-oleh khas Desa Selorejo Blitar. 


\section{SIMPULAN DAN SARAN}

Berdasarkan seluruh kegiatan pada program pengabdian masyarakat oleh tim pelaksana Pengmas Universitas Merdeka Malang dengan sasaran pengrajin Opak Gambir dapat disimpulkan bahwa: (1) Adanya program pengabdian masyarakat melalui pendidikan, pelatihan, serta pembinaan pada pengrajin Opak Gambir di Desa Selorejo Kecamatan Selorejo Kabupaten Blitar menjawab kebutuhan para pengrajin mengenai bagaimana cara mengelola usahanya dari metode konvensional menjadi lebih profesional dan tertata rapi; (2) Penentuan harga pokok penjualan dengan memperhitungkan biaya produksi telah dilakukan sehingga harga jual sudah memperhitungkan jumlah laba yang diinginkan; (3) Transaksi keuangan telah dilakukan dengan pencatatan yang rapi di buku pembukuan khusus; (4) Para pengrajin lebih mudah memonitor jumlah pesanan dan rencana produksi dengan menggunakan pembukuan yang tersusun rapi.

Program pengabdian ini memiliki keterbatasan di sisi pemasaran yaitu promosi. Selain sudah membekali para pengrajin dengan pengetahuan mengenai bagaimana cara mempromosikan produk Opak Gambir, untuk pengabdi kedepannya mungkin bisa menambahkan pelatihan untuk bagaimana melakukan promosi dengan media digital atau sering di sebut sebagai digital marketing. Saran lain yaitu membantu untuk proses legalitas sehingga dengan terdaftarnya produk di perizinan industri rumah tangga akan semakin membuat produk memiliki kekuatan untuk dipasarkan di marketplace yang pada akhirnya bisa mengarahkan kelompok pengrajin ini sebagai destinasi Desa Pengrajin Opak Gambir.

\section{DAFTAR PUSTAKA}

Anam, A., Kurniawan, A., \& Rahardjo, T. (2021). Pelatihan dan pendampingan pemeliharaan ikan lele guna meningkatkan omzet penjualan di Desa Kanigoro Kabupaten Malang. Abdimas: Jurnal Pengabdian Masyarakat Universitas Merdeka Malang, 6(2), 251-259. https://doi.org/10.26905/abdimas.v6i2.5285

Andarini, S. A. (2012). Pemasaran kewirausahaan dan kinerja usaha mikro kecil dan menengah. Jurnal Ekonomika Bisnis, 3(2), 121-130. https://doi.org/10.22219/jekobisnis.v3i2.2235

Asmoro, W. K., Nurfarida, E., \& Wahyu, M. (2019). Peningkatan penjualan olahan Opak Gambir pada industri rumah tangga di Kota Kediri. Seminar Nasional Ekonomi dan Bisnis, 1(1), 71-78.

Cahyani, D. P., Wiyono, B. B., \& Benty, D. D. N. (2020). Pengaruh pendidikan kewirausahaan dan praktik kerja lapangan unit bisnis center terhadap minat berwirausaha. Jurnal Administrasi dan Manajemen Pendidikan, 3(2), 110-117. https://doi.org/10.17977/um027v3i22020p110

Florita, A., Jumiati, \& Mubarak, A. (2018). Pembinaan usaha mikro, kecil, dan menengah oleh Dinas Koperasi dan UMKM Kota Padang. JMIAP: Jurnal Ilmu Administrasi Publik, 1(1), 143-153. https://doi.org/10.24036/jmiap.v1i1.11

Hadiyati, E. (2011). Kreativitas dan inovasi berpengaruh terhadap kewirausahaan usaha kecil. Jurnal Manajemen dan Kewirausahaan, 13(1), 8-16. https://doi.org/10.9744/jmk.13.1.8-16

Jatmiko, J., Endang, R, \& Rojuaniah, M. (2015). Pelatihan ketrampilan masyarakat Balaraja Dalam. Jurnal Pengabdian Masyarakat, 2(1), 138-143. https://doi.org/10.47007/abd.v2i1.1300 
ABDIMAS: Jurnal Pengabdian Masyarakat Universitas Merdeka Malang Volume 6, No. 4, November 2021: 620-628

Kusumawardhani, R., Kurniawan, I. S., Maulida, A., \& Cahya, A. D. (2020). Pelatihan UKM rumahan industri pangan sebagai upaya meminimalkan kendala berwirausaha. Jurnal Pengabdian Kepada Masyarakat (Indonesian Journal of Community Engagement), 6(1), 23-28.

https://doi.org/10.22146/jpkm.46438

Nasrika, N. (2019). Pengembangan sumber daya manusia dalam era globalisasi. Revitalisasi Manajemen Pendidikan Anak Usia Dini (PAUD) di Era Revolusi Industri 4.0, 149-157.

Riyansyah, F., Eif, D., Amin, S., \& Aziz, R. (2018). Pemberdayaan home industry dalam peningkatan ekonomi masyarakat. Jurnal Tamkin, 3(2), 87-109.

Septiani, D. M. (2013). Analisis Tingkat Pendapatan Home Industri Opak Gambir di Desa Sendung,. Malang: Universitas Muhammadiyah Malang.

Syahdan, S. (2019). Peran Industri rumah tangga (home industry) pada usaha kerupuk terigu terhadap pendapatan keluarga di Kecamatan Sakra Kabupaten Lombok Timur. Manazhim, 1(1), 45-63. https://doi.org/10.36088/manazhim.v1i1.136 